Article

\title{
At the Digital Margins? A Theoretical Examination of Social Media Engagement Using Intersectional Feminism
}

\author{
Charlotte Galpin \\ Department of Political Science and International Studies, University of Birmingham, UK; c.a.galpin@bham.ac.uk
}

Submitted: 8 August 2021 | Accepted: 24 September 2021 | Published: 17 February 2022

\begin{abstract}
This article applies an intersectional feminist lens to social media engagement with European politics. Disproportionately targeted at already marginalised people, the problem of online abuse/harassment has come to increasing public awareness. At the same time, movements such as \#BlackLivesMatter and \#MeToo have demonstrated the value of social media in facilitating global grassroots activism that challenges dominant structures of power. While the literature on social media engagement with European politics has offered important insights into the extent to which social media facilitates democratic participation, it has not to date sufficiently accounted for patterns of intersectional activism and online inequalities. Using Nancy Fraser's feminist critique of Habermas' public sphere theory and Kimberlé Crenshaw's theory of intersectionality, this article explores patterns of gender and racial inequalities in the digital public space. By analysing both the role of racist and misogynistic online abuse targeted at women, nonbinary, agender, and gender-variant people in public life, as well as the opportunities for marginalised groups to mobilise transnationally through subaltern counter-publics, I argue that social media engagement is inextricably linked with offline inequalities. To fully understand the impact of social media on European democracy, we need to pay attention to gendered and racialised dynamics of power within the digital public sphere that have unequal consequences for democratic participation. This will involve expanding our methodological repertoire and employing tools underpinned by a critical feminist epistemology.
\end{abstract}

\section{Keywords}

Brexit; digital activism; European public sphere; feminism; intersectionality; online harassment; online violence; populist radical right; social media; transphobia

\section{Issue}

This article is part of the issue "Analyzing Citizen Engagement With European Politics Through Social Media" edited by Pieter de Wilde (Norwegian University of Science and Technology), Astrid Rasch (Norwegian University of Science and Technology), and Michael Bossetta (Lund University).

(C) 2022 by the author(s); licensee Cogitatio (Lisbon, Portugal). This article is licensed under a Creative Commons Attribution 4.0 International License (CC BY).

\section{Introduction}

In this article, I outline a research agenda for an intersectional feminist approach to social media engagement with European politics. This approach offers an account of the way in which social media engagement in Europe is shaped by gender and race as structures of power. These structures reduce opportunities for democratic participation in the digital public sphere for women, nonbinary, agender, and gender-variant people, with particular impacts on those of colour, or trans or queer women. In their report on Toxic Twitter, Amnesty International
(2018) noted that social media abuse is disproportionately targeted towards women, especially women of colour, and is often triggered when sharing opinions about highly politicised topics such as the EU, gender, and race. Amnesty International and the United Nations have recognised online abuse as a human rights violation, linking it with freedoms of expression, assembly, and association that are supposed to be guaranteed with democratic citizenship (Amnesty International, 2018). The European Institute for Gender Equality has argued that cyber violence against women and girls needs to be understood as a form of gender-based violence and 
addressed at an EU level (European Institute for Gender Equality, 2017).

My starting point for this article is that, despite increasing public attention to the role of social media platforms in facilitating online abuse, mainstream scholarship on this topic has largely overlooked such patterns of gender inequality in the digital sphere, stemming from a lack of engagement with feminist theory. Following Nicola J. Smith and Donna Lee, theories of gender and sexuality have been "written out" of political science compared with other social sciences disciplines (Smith \& Lee, 2015, p. 50; see also Kantola \& Lombardo, 2017). Within EU studies, feminist scholars have observed not just the way in which the field renders invisible "the perspectives and experiences of anyone other than White cisgender men" (Guerrina et al., 2018, p. 254), but also the way in which it shapes and reifies political and social hierarchies. Social media scholars have recognised the possibility of exclusion and "uncivil" behaviour as well as the challenges of online filter bubbles for democratic legitimacy. At the same time, they have also analysed the new and inclusive opportunities for transnational democratic engagement with European politics afforded by social media platforms (see e.g., Barisione \& Michailidou, 2017; Bossetta et al., 2018; Brändle et al., 2021; Roose et al., 2017). Yet, these challenges and opportunities of social media are generally discussed in isolation from the gendered and racialised structures of power that underpin them. A feminist approach, then, aims to "challenge strategic silences" in mainstream analysis of social media engagement that "keep traditionally marginal groups...on the periphery" of European politics (Guerrina et al., 2018, p. 254).

Feminist analysis can, however, bring with it its own exclusions (Kantola \& Lombardo, 2017, p. 335). Intersectionality is an approach that highlights the multiple oppressions faced by women of colour. In elucidating her concept of intersectionality, Kimberlé Crenshaw argues that Black women have been "theoretically erased" in the conceptualisation of oppression within "single-axis frameworks" of either gender, race, or class (Crenshaw, 1989, p. 139). While the term originated in Black feminist US legal scholarship in the late 1980s, it describes, as Moya Bailey notes, "a concept that Black feminists have discussed since our earliest preserved writings, speeches, and poetry" (Bailey, 2021). The problem of racist and xenophobic online hate speech has started to be addressed at an international level: In 2016 the EU, for example, introduced a Code of Conduct on Countering Illegal Hate Speech Online (European Commission, 2016) that was agreed with major social media companies. Intersectionality, however, acknowledges the differences not just between but also within groups, drawing attention to the experiences of women and nonbinary, agender, and gender-variant people of colour who do not just experience racism and sexism simultaneously, but a combination of oppressions that is greater than the sum of its parts (Crenshaw, 1989, p. 140).
In more recent scholarship, intersectionality has been expanded to encompass a wider range of categories such as sexuality, religion, ethnicity, and ability that are, according to Patricia Hill Collins, "best understood in relational terms rather than in isolation from one another" (Collins, 2015, p. 14). Despite a wide range of intersectional studies from the US context and feminist cultural and media studies (see e.g., Brown et al., 2017; Jane, 2014; Kanai \& McGrane, 2020; Sobande, 2020), literature on social media engagement with European politics has skimmed over the topic of intersectional experiences of social media.

To understand the conditions under which citizens engage in European politics on social media, we therefore need to consider the online experiences of already marginalised groups, and their wider consequences for European democracy. I argue that this task has several dimensions: (a) engaging with feminist critiques of public sphere theory; (b) applying intersectional theory to consider inclusiveness not just in terms of transnational communication but also gender, racial, and sexual diversity; and (c) considering the online sphere as inextricably linked to the offline sphere. To do this I draw on both Nancy Fraser's feminist critique of Habermas' public sphere theory (Fraser, 1992) and Kimberlé Crenshaw's theory of intersectionality (Crenshaw, 1989, 1991). I then explore two key themes: online abuse as "participatory inequality" and "subaltern counter-publics" as potential spaces of resistance using empirical examples primarily from the UK and Germany. These examples relate to EU/Brexit debates as well as broader transnational issues that are likely to appear simultaneously across European national public spheres (Bossetta et al., 2017, p. 71). I argue that, in order to fully understand the opportunities and challenges arising from social media for democracy, an intersectional approach to citizens' engagement is required that pays attention to gendered and racialised dynamics of power within the digital public sphere that have unequal consequences.

Some brief content notes: Firstly, I cite examples of misogynistic and racist abuse directed at women in European public life. Taking on board Emma A. Jane's argument that there has been a "tyranny of silence" within academic literature about the sexually violent discourse directed at individuals on social media (Jane, 2014, p. 533), I provide uncensored quotes. While these may be shocking to read, I am quoting messages purposefully cited by the recipients themselves. In so doing I hope that I have honoured the agency of these women who have spoken publicly about their experiences of online abuse. Secondly, in line with intersectional feminism's recognition of difference, I seek to avoid a reification of the binary gender categories of "woman" and "man." In this article, I have adopted Moya Bailey's phrase of "women, nonbinary, agender, and gendervariant folks" (Bailey, 2021) to recognise that not only women experience gender-based oppression but also anyone who falls outside the dominant gender binary. 


\section{Social Media Engagement and Intersectional Feminist Theory}

\subsection{Social Media and European Democracy}

There is a wide literature on social media engagement with European/EU politics that has contributed important, in-depth analyses of the impact of social media on European democracy. Yet, few studies explicitly theorise the way in which gender and race shape this engagement. Resting upon normative theories of the public sphere (Habermas, 1984, 1999), social media is conceptualised as a digital public sphere that now plays a key role in transnational democratic participation in European politics (see e.g., Barisione \& Michailidou, 2017; Michailidou et al., 2014). Mauro Barisione and Asimina Michailidou, for example, see social media "both as a public space for opinion expression and formation and as a resource for citizen mobilisation and collective action" (Barisione \& Michailidou, 2017, p. 8). Particularly for young voters or "ordinary citizens" the internet is understood to be an opportunity for engagement in public debates as well as for political activism (Michailidou et al., 2014, p. 17). According to Michael Bossetta et al., social media carries a "participatory promise" by helping users develop political knowledge and mobilise in new ways outside the formal political and mainstream media arena (Bossetta et al., 2017, p. 54). Such participation is considered crucial for political legitimacy, both at the EU and national level. Social media is seen as having facilitated a "social media demos" that "exerts unprecedented power" within the EU (Barisione \& Michailidou, 2017, p. 9) through a more critical debate about European politics and policy.

These rather optimistic accounts of the digital public sphere have, however, also been met with more critical analyses. Literature on social media engagement in Europe has focused on the damaging impact of so-called "filter bubbles" or "echo chambers" in which people build largely closed spaces of communication (Flaxman et al., 2016). Such spaces result in "disrupted" public spheres and declining trust in institutions (Bennett \& Pfetsch, 2018). For example, significant ideological and largely nationally-contained cleavages were found within pro-EU and Eurosceptic party networks on Twitter (Heft et al., 2017). I agree with Michailidou et al. that a straightforward delineation of social media as "facilitating or constraining political action" (Michailidou et al., 2014, p. 31) is difficult given the dynamics of online communication. Yet, I argue that an intersectional approach that explicitly addresses the experiences of especially Black, migrant, minority, and trans women, as well as nonbinary, agender and gender-variant people, is essential for understanding democracy in the social media age. This would help to better capture the exclusions and opportunities of social media not just for citizens in general, but for the most marginalised groups. In this way, we can more fully assess the extent of not just the "participa- tory promise" (Bossetta et al., 2017) of social media as an open and equal space for debate about European politics but also its "emancipatory potential" (Fraser, 1992; Habermas, 1999).

\subsection{The Digital Public Sphere and Intersectional Feminist Critiques}

An intersectional feminist approach unpacks several dominant binaries within the literature: a public/private binary, a national/transnational binary, and an online/offline binary. Firstly, the idea of social media as a space for public deliberation and collective European will-formation rests upon a traditional distinction between the public and private spheres that reproduces long-standing gendered hierarchies and exclusions. According to Nancy Fraser, public opinion can be considered legitimate to the extent that it is inclusive"open to all with a stake in the outcome" as well as guaranteeing participatory parity-offering participants "roughly equal chances to state their views" (Fraser, 2007, p. 61). Yet, she argues, Habermas' theory of the public sphere violates that principle, as it is predicated on a separation between the "public" domain of work and politics, from the "private" domain of family and intimacy. This has come to denote the "hegemonic mode of domination" (Fraser, 1992, p. 62) underpinning modern capitalist societies, situating bourgeois (white) women outside of citizenship and in the home (working class women especially of colour were nevertheless expected to work, often in the private sphere, to facilitate this). The public/private dichotomy is underpinned by a rational/emotional and mind/body divide that originated, as Charlotte Hooper notes, in an Enlightenment "fantasy of disembodiment" that strove for a separation of reason from the vulgarities of physicality, emotions, and desires (Hooper, 2000, p. 39).

While Fraser's work calls upon feminists to analyse gender "as one axis of inequality among others" (1989, p. 12), she has not explicitly used intersectionality. Intersectionality, as Patricia Hill Collins argues, is first and foremost interested in the intersecting structures of power that create "complex social inequalities that are organized via unequal material realities and distinctive social experiences for people who live within them" (Collins, 2015, p. 14). Crenshaw identifies three distinct forms of intersectionality: (a) structural, i.e., the different socio-economic and institutional locations of women of colour (Crenshaw, 1991, p. 1250), (b) political, the marginal location of women of colour within both anti-racist and feminist interest groups, and (c) representational, the way in which women of colour are represented through dominant cultural narratives of race and gender (Crenshaw, 1991, p. 1283). Intersectionality matters for the public sphere: While the private sphere was reserved for bourgeois white women who were considered capable of feeling, it was the denial of Black people's humanness altogether that served to justify 
the European colonial project and the enslavement of African people (Phipps, 2021, p. 87).

Secondly, then, intersectional analysis can help to understand social media's role in facilitating inclusive public deliberation about European politics in a way that recognises the diversity of contemporary Europe (Siim, 2012 , p. 4). Social media facilitates cross-border political communication as part of its "transnational promise" (Bossetta et al., 2017, p. 54), expected to connect citizens "across national borders and political levels" within a European digital public sphere (De Wilde et al., 2014, p. 3). Yet, following Gurminder K. Bhambra, the focus on diversity between EU member states should not be prioritised over the multicultural diversity within them that has resulted from European colonialism (Bhambra, 2015, p. 192). For Fraser, a legitimate transnational public develops under the "all-affected" principle in which people come together to debate issues relevant to them not because of formal citizenship but because their lives are all affected by the same national, transnational or supranational structures (Fraser, 2007, p. 63). Intersectionality therefore asks: To what extent are women, nonbinary, agender, and gender-variant people, especially trans women and those of migrant and minority backgrounds, able to participate in social media debates about European politics? This question extends our analysis beyond the concepts of functional or geographical inclusiveness (see e.g., Roose et al., 2017) to include patterns of domination, subordination, and empowerment in a way that centres traditionally marginalised people as agents rather than (often invisible) objects of European politics.

Finally, intersectional feminist theory helps us to understand people engaging in public debates on social media as embodied, with offline lives and experiences. Existing literature on social media engagement with European politics has implicitly constructed an artificial binary between the "online" and "offline" spheres that also reproduces the mind/body divide. Disembodied internet users engaging in "rational" debate are imagined separately from offline structures of privilege and exclusion. Instead, Beth E. Kolko et al. call upon us to consider the "situatedness of the disembodied cyberself" (Kolko et al., 2000, p. 6). which, Francesca Sobande notes, is "always tethered to, and, by, different geographies and their borders and boundaries" (Sobande, 2020, p. 106). While to a certain extent social media allows for anonymity and invisibility, users also cannot "log in and simply shrug off a lifetime of experiencing the world from specific identity-related perspectives" (Kolko et al., 2000, p. 6). It is this separation of the offline and online spheres, Tegan Zimmerman argues, that both silences marginalised groups online and overlooks the possibilities for intersectional activism on social media (Zimmerman, 2017, p. 58).

In the following, I demonstrate the way in which analysing the online abuse of women and the possibilities for subaltern digital counter-publics sheds light on the extent to which social media as digital public spheres inhibit or facilitate "inclusiveness" and "participatory parity" as essential for a democratic transnational public sphere (Fraser, 1992, 2007).

\section{Online Abuse as Participatory Inequality}

Social media has been imagined as a space where "everybody is invited to participate" in European politics (see e.g., Roose et al., 2017, p. 271). This conception of social media follows from Habermas' argument that open access to the public sphere can be ensured by "disregarding" differences in status and coming together in debate as equals (1999, p. 50). Despite formal inclusion, women, nonbinary, agender and gender-variant folks, people of colour, and other marginalised groups face informal exclusions due to a "masculine" style of deliberation that results in silencing, preventing them from "participating as peers" (Fraser, 1992, p. 60). The interrupting, ignoring, mishearing, or dismissing of women's contributions demonstrates that public deliberation "can serve as a mask for domination" in which social inequalities are not "bracketed" but shape people's opportunities to participate (Fraser, 1992, p. 64). Scholars have acknowledged that online debates about European politics often do not conform to "deliberative" standards of argumentation, often including "uncivil" and derogatory comments and unrepresentative, mostly male users (Chen \& Pain, 2017; Galpin \& Trenz, 2019; Southern \& Harmer, 2019). Such comments are juxtaposed with "civic" styles of engagement that respect generally accepted rules of good behaviour and are discounted as activity not reaching the standards of citizenship practice (Bossetta et al., 2017, p. 60). From a feminist perspective, however, the nature of such "non-civic" participation matters for how the digital public sphere relates to intersecting "offline" inequalities (Zimmerman, 2017, p. 62), resulting in unequal consequences for online democratic engagement.

Women, nonbinary, agender, and gender-variant people experience gendered forms of online abuse that inhibit their opportunities for engaging with European politics. While cis men also experience online harassment, people of marginalised genders receive messages that are misogynistic in nature and that objectify or sexualise them, replicating and multiplying experiences also faced in the "real" world (Hackworth, 2018, p. 52). Social media users come together not only to reason, learn, and debate about European politics, but also, as Jane highlights, to oppress and injure in particularly gendered ways (Jane, 2014, p. 539). Rape threats, she notes, have become the "modus operandi" for criticising women in public life (Jane, 2014, p. 535). Ahead of the 2019 European elections, the United Kingdom Independence Party (UKIP) was criticised for selecting the prominent anti-feminist and far-right YouTuber Carl Benjamin (known as Sargon of Akkad) as a candidate. In response to her campaigns against online misogyny, Benjamin had in 2016 tweeted UK Labour MP 
Jess Phillips that he "wouldn't even rape" her, clarifying in a new video in 2019 that "with enough pressure, I might cave" (Syal, 2019). A number of women MPs such as former Conservative (later ChangeUK) Anna Soubry reported receiving extreme and often sexually violent abuse and death threats while participating in Brexit debates such as "lol get jo coxed you old bint," referring to the Labour MP Jo Cox who was assassinated during the 2016 EU referendum ("MP Anna Soubry," 2016; Walker, 2017). Online messages also translated into verbal and physical harassment on the street. As I have argued elsewhere in an account of my own experience of sexual harassment following a public lecture, sexualised violence symbolically reduces women in the public sphere to their bodies, transporting them out of the public arena into the private sphere of sexuality (Galpin, 2020).

Representational intersectionality draws attention to the way in which online harassment is "multilayered in nature" and experienced differently by women of colour, trans women, and people of other marginalized genders (Hackworth, 2018, p. 56). Such experiences cannot be studied in isolation: Harassment of women of colour typically draws on dominant stereotypes of Black or minority women, while harassment of trans and queer people will often be homophobic or transphobic in nature (Hackworth, 2018, p. 58). The Black Labour MP Diane Abbott has been found to receive almost half of all Twitter abuse directed at women MPs (Amnesty International, 2018, p. 17). Abbott has recounted death and rape threats, messages describing her as an "ugly fat black bitch," and countless uses of the N-word (Parliament TV, 2017). Gina Miller, the Black British businesswoman and campaigner who successfully took the British government to court over its plans to trigger Article 50 of the Lisbon Treaty without parliament's consent, has reported threats of death, gang rape, and dehumanising racist slurs that, for example, described her as "just an ugly ape who needs whipping into obedience" and threatened that a "Jo Cox killing would be too good for you" (Anthony, 2018). Jewish women such as Labour (later ChangeUK/Liberal Democrat) MP Luciana Berger, have also been subject to violent anti-Semitic abuseBerger received messages calling her a "vile fifth columnist," an "agent for a foreign power" and "Zionist scum" (Urwin, 2020). As a form of representational intersectionality, such examples demonstrate the way in which racist violence intersects with misogyny for women of colour and religious minorities engaging in European politics to reproduce specific discriminatory tropes. While white women MPs are symbolically removed from the public into the private, Black, Asian, Jewish, and Muslim women are dehumanised altogether.

The problem of online violence against women is not limited to the UK, but has been documented across Europe particularly in the context of immigration debates. Abusive discourses involving sexism/misogyny and racism are likely to be situated within national and transnational contexts (Siim, 2014, p. 118). For example, the Afro-German writer and anti-racist activist Jasmina Kuhnke was forced to move her entire family in 2021 as a result of having her address published online (known as being "doxxed") in a video involving death threats and racist images of her portrayed as an ape (Straatmann, 2021). Sawsan Chebli, a German Social Democrat politician, has also spoken of receiving extreme misogynistic and racist abuse, often orchestrated by the far-right party Alternative for Germany (AfD) and particularly after contributing to debates about the \#MeToo movement (Kiesel, 2017). While the quote above sent to Miller reproduces a common trope about Black women as subject to the control and punishment of white men (Bailey, 2021), messages received by Kuhnke such as "You gotta ask yourself, how did she squeeze those brats out of that scrawny junkie-arse?," "be thankful we brought you out of the jungle, you dirty creature!" and "get the slave-trader there and let him take her away" (my translations) indicate the links between online abuse, misogyny, and wider discourses of European colonialism. Abuse directed at Black and minority women therefore uses dehumanising and derogatory images and stereotypes that result in them being "uniquely denigrated because of their gender and race" (Bailey, 2021).

Social media companies have developed limited policies on hate speech and harassment, while users' access to justice and protection depends on national legislation that diverges across Europe. The UK has used the 2003 Communications Act to prosecute some of the most violent offenders, such as the businessman Viscount Phillips who offered $£ 5,000$ for Gina Miller's death in a Facebook post using racist slurs. Germany has legislated against social media companies directly through the 2017 Netzwerkdurchsetzungsgesetz-the Network Enforcement Act, or "Facebook Act" that requires social media companies to take more effective action against hate speech. While the law has been criticised for threatening free speech, such legal measures also conceptualise online violence as individual acts rather than organised "networked misogyny" (Bratich \& Banet-Weiser, 2019). Structural intersectionality also shapes the type of support and response one will receive from the authorities (Crenshaw, 1991). Jasmina Kuhnke has recounted that, after turning to the police for protection when strangers started to turn up at her door, she was refused help on the grounds that there was no evidence of a threat. A YouTuber, incidentally a former policeman, who had targeted Sawsan Chebli was exonerated in court on the grounds of "free speech" for describing her as, amongst other things, an "Islamic talking doll" ("Bittere Nachricht für alle," 2020). Moves to address misogyny as a hate crime through the criminal justice system (see e.g., Scott, 2020) risks therefore taking the form of white feminism that fails to consider the impact of increased policing on people of colour.

Such abuse is a form of gender-based and racial violence that intends to exclude certain bodies from democratic debate. Kirsti K. Cole has argued that online 
violence constitutes "disciplinary rhetoric" with the goal to "silence the women participating in public" (Cole, 2015 , p. 356). Bridget Gelms has coined the term "volatile visibility" to describe the "abusive and potentially dangerous consequences that arise from particular moments of online publicity" (Gelms, 2020). Women often turn to self-censorship, through anonymity, changing what they write about or withdrawing from social media altogether (Jane, 2014, p. 536). Jess Phillips has spoken of her need to place heavy restrictions on her Twitter feed, which reduced her ability to engage with constituents, while Sawsan Chebli was forced to deactivate her Facebook account. Eighteen women MPs stepped down from the UK Parliament in 2019, many citing the impact of the abuse they received (Perraudin \& Murphy, 2019). The murder of Jo Cox and the experiences of women such as Jasmina Kuhnke demonstrate the very real risk faced by women, nonbinary, agender, and gender-variant people in public life that is not limited to the digital world but extends to offline threats to life. Yet, we know very little about the secondary impact the abuse of women in public life has on younger or lower-profile people who may otherwise have chosen to use their voice in public debates but opt out because of the likelihood of abuse/harassment.

\section{Subaltern Digital Public Spheres-Spaces of Resistance?}

Despite the abuse and violence to which many are subjected online, social media can also provide spaces of resistance for minoritized groups. The possibility of multiple digital public spheres is acknowledged as a way for marginalised groups to become empowered through the particular platform affordances of social media (see e.g., Barisione \& Michailidou, 2017, p. 15). Yet, the possibilities for such engagement with European politics requires further theoretical specificity. Nancy Fraser argues that a single, comprehensive public sphere is undesirable in unequal societies. Instead, she envisages "subaltern counter-publics" as "parallel discursive arenas where members of subordinated social groups invent and circulate counterdiscourses" (Fraser, 1992, p. 67). Through subaltern counter-publics, narrow understandings of "public" and "private" matters that exclude certain topics from debate can be expanded to incorporate marginalised group interests (1992, p. 73). Akane Kanai and Caitlin McGrane introduce the concept of a "feminist filter bubble," defined as "digital spaces in which sexist, misogynist and anti-feminist content is 'filtered out' so that focused feminist content and discussions can occur" (Kanai \& McGrane, 2020, p. 2). Such spaces constitute a "vital form of protection" for feminist debate that has, for many, become a "material necessity" on social media (Kanai \& McGrane, 2020, p. 2).

"Filtering practices" provide essential tools for feminist and anti-racist activism around global, transnational, and European issues that can mobilise alternative dis- courses and spark wider change (Wahba, 2016, p. 66). The \#BlackLivesMatter and \#MeToo movements have demonstrated the value of social media in facilitating global grassroots activism by offering a platform to people usually marginalised from mainstream media and formal politics and an opportunity to challenge mainstream narratives. Originating as a hashtag in 2013, \#BlackLivesMatter resulted in widespread protests in 2020 not just in the US but also across Europe, bringing conversations about structural racism and colonial legacies to a wider public. \#MeToo offered people a way to publicly share their experiences of sexual assault. Within EU debates specifically, dedicated grassroots women's campaigns have emerged such as the UK-based "Women Against Hate" (formerly Women Against UKIP) Facebook page, the German-based "Frauen Gegen die AfD" (Women Against the AfD) page and the Austrian "Omas Gegen Rechts" (Grandmas Against the Right). Social media also facilitates intersectional mobilisation. Black women use social media to communicate and build community across local, regional, and national borders (Sobande, 2020, p. 106). Extending from the US to encompass cases in the UK and wider Europe, the \#SayHerName campaign is a "transnational, intersectional narrative" aimed at raising awareness of Black cis and trans women victims of police brutality overlooked in mainstream discourse (Brown et al., 2017, p. 1841). As Moya Bailey finds, such practices of resistance by Black women constitute "a form of self-preservation and harm reduction that disrupts the onslaught of the problematic images that society perpetuates" (Bailey, 2021).

Yet, spaces of resistance also create different forms of exclusion and marginalisation. As Kanai and McGrane note, feminist filter bubbles may not automatically be safe for everybody (2020, p. 2). Akwugo Emejulu's analysis of the anti-Trump Women's Marches (Emejulu, 2018) and Allison Phipps' examination of white feminism in the \#MeToo movement demonstrate the way in which narratives of white women's victimhood have reproduced "colonial archetypes of people of colour as aggressive and frightening" (Phipps, 2021, p. 84), resulting in discursive overlap and indeed complicity with radical right politics in Europe. Using Crenshaw's political intersectionality, we can see how women of colour, trans women, and nonbinary, agender, and gender-variant people are excluded from feminist campaigns through the universalisation of white cis women's experiences (Crenshaw, 1991, p. 1252). In the European public sphere, the incorporation of gender equality into understandings of the nation has othered Muslim men and silenced Muslim women's voices within gender activism (Siim, 2014 , p. 122). This pattern became visible in responses to the Cologne sexual assaults on New Year's Eve 2016, which, despite anti-racist feminist attempts to change the discourse via the Twitter campaign \#ausnahmlos (\#noexcuses), resulted in a crackdown on immigration and deportations of Muslim refugees (Boulila \& Carri, 2017). Islamophobic tweets that called for the protection 
of "Western" women from Muslim men were prominent during the Brexit referendum (Evolvi, 2018, p. 11).

Recent years have also seen a concerning increase in transphobic discourse online (Brandwatch \& Ditch The Label, 2019). The increasing focus of nationalist movements in Europe on LGBTQ+ rights has also found social media support amongst trans-exclusionary radical feminists whose objective is to bar trans women from so-called "women-only spaces" (Anarchasteminist \& Moore, 2021). Online transphobia has materialised in legislation in context-specific ways: According to Ruth Pearce et al., at the same time that Hungarian President Viktor Orbán tabled anti-trans laws under the guise of conservative nationalist family values, the UK government was proposing anti-trans policies via the discourse of "'respectable' middle-class feminism" (Pearce et al., 2020, p. 884). As Allison Phipps notes, trans-exclusionary campaigns rely on "accounts of sexual victimisation, set alongside a construction of trans women as predatory and essentially male" (Phipps, 2021, p. 88). Such movements construct trans women as "monsters" who are then ousted from both the public and private domainsthereby refused access to online subaltern feminist counter-publics but also denied the humanity of "complex feelings or to claim victimhood on their own behalf" (Phipps, 2021, pp. 88-89). Following Allison Phipps, then, white cis women are able to claim a space within online public spheres but do this through the marginalisation and also dehumanisation of trans women and people of colour (Phipps, 2021, p. 90).

The same platforms that allow for the development of subaltern counter-publics that contribute to the "emancipatory potential" of the public sphere therefore also facilitate the development of counter-publics that may be damaging for democratic engagement. Literature on social media engagement in European politics has noted the way in which social media has facilitated the rise to prominence of so-called "counter-elites" such as, for example, Donald Trump (Michailidou et al., 2014, p. 39). The development of closed online communities has also been associated with the radicalisation of extreme-right groups in Europe (Pavan \& Caiani, 2017). Jess Phillips' report of receiving over 600 rape threats on Twitter in one night following Carl Benjamin's tweet (Snowdon, 2018) is one example of how online abuse is often orchestrated as "networked misogyny" (Bratich \& Banet-Weiser, 2019). Yet, we have a limited understanding of the links between the anti-feminist "manosphere," transphobic groups, and radical right and extremist movements that impact on wider debates about political institutions and legitimacy.

Finally, structural intersectionality demonstrates how participation in subaltern counter-publics can be impeded by social media algorithms, policies, and platform affordances that perpetuate systemic discrimination. As Michailidou et al. argue, effective social media engagement requires not just being "allowed to speak out but to be heard" (2014, p. 64). Platforms influence this ability through the demotion of content and more extreme measures such as account deletion and shadowbans-techniques which prevent accounts and content from appearing in search results or user news feeds (Are, 2021, pp. 2, 13). Caroline Are traces the "shadowban cycle" in which social media companies, responding to public pressure over online abuse, "hit an easy target" of women's bodies (Are, 2021, pp. 13-14). The removal of content that is deemed unacceptably "sexual" or "private" has a disproportionate impact on women, LGBTQ+ people, sex workers, and people of colour, who may depend on social media for income or are constructed in overly sexualised ways in (trans)misogynistic discourse (Are, 2021, p. 3). Social media platforms determine who has a right to an online public presence, and who does not, through decisions shaped by business logics and dominant socio-cultural norms about acceptability (Gillespie, 2015, p. 2).

These exclusions matter, infringing the "all-affected principle" of the transnational public sphere. Radical right and nationalist parties promote conservative family values that target $L G B T Q+$ and gender equality rights, while their calls to strengthen border controls to crack down on "sex trafficking" result, as Nicola J. Smith notes, in policies that actually put migrant sex workers at greater risk of exploitation (Smith, 2020, p. 119). In the UK, sex workers from EU-27 countries have been arrested or deported from Britain due to lacking the legal documentation of waged work required to obtain "settled status" following Brexit (Smith, 2020, p. 120). The effect of account deletions and shadowbans by social media companies is to reduce the opportunities of those most affected by such movements to mobilise in political debate. Social media platforms are not, therefore, akin to a modern inclusive "town square" or "coffee house" where "everybody is invited to participate" but capitalist structures that reproduce offline inequalities and patterns of gendered and racialised exclusion.

\section{Conclusion}

The literature on social media engagement in Europe has demonstrated both the possibilities for transnational online engagement with European politics alongside the risks posed by filter bubbles and radical right and nationalist counter-publics for European democracy. The application of intersectional feminist theory aims to build on this work by exploring the possibilities for and barriers to social media participation through the lens of gender and race. There are two vital areas of research here that are "underpinned by a pressing ethical imperative" (Jane, 2014, p. 542): firstly, to gain a deeper understanding of the nature of online violence directed at women, nonbinary, agender, and gender-variant people within social media debates about European politics; secondly, to better understand the impact this violence is having on inclusive and participatory democratic debate about European politics; and thirdly, to 
understand the opportunities and barriers created by social media for spaces of resistance. If debates about European politics are considered to be taking place in transnational digital spaces, and particular groups are either actively/violently excluded or marginalised through self-censorship, such debates cannot be democratically legitimate.

Such a research agenda nevertheless presents social media scholars with methodological challenges. Quantitative content or sentiment analysis of "big data" - often in collaboration with computer scientistsis mainstream within the political science literature, identifying the issues raised and actors engaged in public social media communication, as well as the geographical or territorial scope of debates. Discourse analysis of online tweets and comments is also common, while social network analysis is growing as a key approach. Yet, while offering the possibility of valuable and much needed data, such methods will only take us so far in the study of online abuse and resistance through subaltern counter-publics due to ethical and practical limitations. Firstly, much of the data required is not "public." Abusive or harassing messages are often sent privately through direct messages (DMs) or emails and often orchestrated via message boards and communities on the "dark web." While of course a lot of hateful or abusive messages are circulated in the public domain, many of the worst comments can nevertheless be moderated, especially on public pages with attentive administrators.

Secondly, studies typically decide a priori what constitutes "non-civic" or "abusive" content, focused on developing "uniform criteria" for content that violates democratic norms (Jane, 2014, p. 537). Yet, what is considered "abusive," "hostile" or "threatening" to one person may be perceived very differently to another. As such, Emma A. Jane's definition of "e-bile" is left open-requiring solely the use of technology and being "perceived by a sender, receiver, or outside observer as involving hostility" (Jane, 2014, p. 533). Our understanding of online abuse needs to shift from an exclusive focus on content to an analysis of the impact on individuals and the wider democratic system. Thirdly, resistance practices within subaltern counter-publics are likely to take place in, for example, closed groups on Facebook, or as community conversations via hashtags or temporary stories outside of "mainstream" forums and arenas. The nature of subaltern counter-spheres is often that they cannot be ethically studied without the explicit consent and approval of community members and may need to involve researchers who belong to the communities being analysed.

To answer intersectional questions about social media engagement in Europe, we therefore need to expand our methodological repertoire and consider tools such as digital ethnography, interviews, surveys, participatory and arts-based research, and more. The use of such tools, furthermore, needs to be underpinned by a reflexive and critical feminist epistemology that examines issues of power in academic research and explicitly aims at the transformation of gender and racial oppression in European politics in both the online and offline spheres. Such tools are already in use amongst (Black) feminist media scholars (see e.g., Bailey, 2021; Sobande, 2020), yet, conspicuous by their absence in political science.

\section{Acknowledgments}

Many thanks to Tara Windsor, Fran Amery, and Patrick Vernon for alerting me to some of the sources used in this article, to the POLSIS Writing Group for facilitating the development of this piece, and to the two anonymous reviewers for their helpful feedback. This publication is published with the support of the Erasmus+ programme of the European Union. It is part of the Jean Monnet Networks project "Post-Truth Politics, Nationalism and the (De)Legitimation of European Integration."

\section{Conflict of Interests}

The author declares no conflict of interests.

\section{References}

Amnesty International. (2018). \#ToxicTwitter: Violence and abuse against women online. https://www. amnesty.org/en/documents/act30/8070/2018/en

Anarchasteminist, \& Moore, M. (2021, March 18). Alert: Transphobic feminism and far right activism rapidly converging. Trans Safety Network. https:// transsafety.network/posts/gcs-and-the-right

Anthony, A. (2018, August 19). Gina Miller: "I was absolutely shocked, I didn't know those attitudes still existed." The Guardian. https://www.theguardian. com/politics/2018/aug/19/gina-miller-rise-lifelessons-in-speaking-out-brexit-hatred-interview

Are, C. (2021). The shadowban cycle: An autoethnography of pole dancing, nudity and censorship on Instagram. Feminist Media Studies. Advance online publication. https://doi.org/10.1080/14680777.2021. 1928259

Bailey, M. (2021). Misogynoir transformed: Black women's digital resistance. New York University Press.

Barisione, M., \& Michailidou, A. (Eds.). (2017). Social media and European politics: Rethinking power and legitimacy in the digital era. Palgrave Macmillan.

Bennett, W. L., \& Pfetsch, B. (2018). Rethinking political communication in a time of disrupted public spheres. Journal of Communication, 68(2), 243-253.

Bhambra, G. K. (2015). Whither Europe? Postcolonial versus neocolonial cosmopolitanism. Interventions, 18(2), 1-16.

"Bittere Nachricht für alle, die von Hetze betroffen sind" ["Bitter news for everyone affected by harassment campaigns"]. (2020, February 28). Frankfurter 
Allgemeine Zeitung. https://www.faz.net/aktuell/ politik/inland/fall-sawsan-chebli-youtuber-wirdfreigesprochen-16655812.html

Bossetta, M., Dutceac Segesten, A., \& Trenz, H.-J. (2017). Engaging with European politics through Twitter and Facebook: Participation beyond the national? In $\mathrm{M}$. Barisone \& A. Michailidou (Eds.), Social media and European politics (pp. 53-76). Palgrave.

Bossetta, M., Dutceac Segesten, A., \& Trenz, H.-J. (2018). Political participation on Facebook during Brexit: Does user engagement on media pages stimulate engagement with campaigns? Journal of Language and Politics, 17(2), 173-194.

Boulila, S. C., \& Carri, C. (2017). On Cologne: Gender, migration and unacknowledged racisms in Germany. European Journal of Women's Studies, 24(3), 286-293.

Brändle, V. K., Galpin, C., \& Trenz, H.-J. (2021). Brexit as "politics of division": Social media campaigning after the referendum. Social Movement Studies. Advance online publication. https://doi.org/ 10.1080/14742837.2021.1928484

Brandwatch, \& Ditch The Label. (2019). Exposed: The scale of transphobia online. https://www. brandwatch.com/reports/transphobia

Bratich, J., \& Banet-Weiser, S. (2019). From pick-up artists to incels: Con(fidence) games, networked misogyny, and the failure of neoliberalism. International Journal of Communication, 13, 5003-5021.

Brown, M., Ray, R., Summers, E., \& Fraistat, N. (2017). \#SayHerName: A case study of intersectional social media activism. Ethnic and Racial Studies, 40(11), 1831-1846.

Chen, G. M., \& Pain, P. (2017). Normalizing online comments. Journalism Practice, 11(7), 876-892.

Cole, K. K. (2015). "It's like she's eager to be verbally abused": Twitter, trolls, and (en)gendering disciplinary rhetoric. Feminist Media Studies, 15(2), 356-358.

Collins, P. H. (2015). Intersectionality's definitional dilemmas. Annual Review of Sociology, 41(1), 1-20.

Crenshaw, K. (1989). Demarginalizing the intersection of race and sex: A Black feminist critique of antidiscrimination doctrine, feminist theory and antiracist politics. University of Chicago Legal Forum, 1989(1), 139-167.

Crenshaw, K. (1991). Mapping the margins: Intersectionality, identity politics, and violence against women of color. Stanford Law Review, 43(6), 1241-1299.

De Wilde, P., Michailidou, A., \& Trenz, H.-J. (2014). Converging on Euroscepticism: Online polity contestation during European Parliament elections. European Journal of Political Research, 53(4), 766-783.

Emejulu, A. (2018). On the problems and possibilities of feminist solidarity: The Women's March one year on. IPPR Progressive Review, 24(4), 267-273.

European Commission. (2016). The EU code of conduct on countering illegal hate speech online. European
Union. https://ec.europa.eu/info/policies/justiceand-fundamental-rights/combattingdiscrimination/racism-and-xenophobia/eu-codeconduct-countering-illegal-hate-speech-online_en

European Institute for Gender Equality. (2017). Cyber violence against women and girls. https://eige. europa.eu/publications/cyber-violence-againstwomen-and-girls

Evolvi, G. (2018). Hate in a Tweet: Exploring internetbased Islamophobic discourses. Religions, 9(10), Article 307.

Flaxman, S., Goel, S., \& Rao, J. (2016). Filter bubbles, echo chambers, and online news consumption. Public Opinion Quarterly, 80(Suppl. 1), 298-320.

Fraser, N. (1989). Unruly practices : Power, discourse, and gender in contemporary social theory. University of Minnesota Press.

Fraser, N. (1992). Rethinking the public sphere: A contribution to the critique of actually existing democracy. In C. Calhoun (Ed.), Habermas and the public sphere (pp. 109-142). MIT Press.

Fraser, N. (2007). Transnationalizing the public sphere: On the legitimacy and efficacy of public opinion in a post-Westphalian world. Theory, Culture \& Society, 24(4), 7-30.

Galpin, C. (2020, January 31). On resisting. Feminist Academic Collective. https://feministacademiccollective. wordpress.com/2020/01/31/on-resisting

Galpin, C., \& Trenz, H.-J. (2019). Participatory populism: Online discussion forums on mainstream news sites during the 2014 European Parliament election. Journalism Practice, 13(7), 781-798.

Gelms, B. (2020). Volatile visibility: How online harassment makes women disappear. In J. Reyman \& E. M. Sparby (Eds.), Digital ethics: Rhetoric and responsibility in online aggression (pp. 179-194). Routledge.

Gillespie, T. (2015). Platforms intervene. Social Media + Society, 1(1). https://doi.org/10.1177/205630511 5580479

Guerrina, R., Haastrup, T., Wright, K. A. M., Masselot, A., MacRae, H., \& Cavaghan, R. (2018). Does European Union studies have a gender problem? Experiences from researching Brexit. International Feminist Journal of Politics, 20(2), 252-257.

Habermas, J. (1984). Theory of communicative action. Volume I: Reason and the rationalization of society. Beacon Press.

Habermas, J. (1999). The structural transformation of the public sphere. An inquiry into a category of bourgeois society. MIT Press.

Hackworth, L. (2018). Limitations of "just gender": The need for an intersectional reframing of online harassment discourse and research. In J. R. Vickery \& $\mathrm{T}$. Everbach (Eds.), Mediating misogyny (pp. 51-70). Palgrave Macmillan.

Heft, A., Wittwer, S., \& Pfetsch, B. (2017). Divided they Tweet? A comparative analysis of Twitter networks of pro- and anti-EU parties. In M. Caiani \& 
S. Guerra (Eds.), Euroscepticism, democracy and the media: Communicating Europe, contesting Europe (pp. 195-218). Palgrave Macmillan.

Hooper, C. (2000). Disembodiment, embodiment and the construction of hegemonic masculinity. In G. Youngs (Ed.), Political economy, power and the body : Global perspectives (pp. 31-51). Macmillan.

Jane, E. A. (2014). "Your a ugly, whorish, slut." Feminist Media Studies, 14(4), 531-546.

Kanai, A., \& McGrane, C. (2020). Feminist filter bubbles: Ambivalence, vigilance and labour. Information, Communication \& Society. Advance online publication. https://doi.org/10.1080/1369118X.2020.1760916

Kantola, J., \& Lombardo, E. (2017). Feminist political analysis: Exploring strengths, hegemonies and limitations. Feminist Theory, 18(3), 323-341.

Kiesel, R. (2017, December 28). Sawsan Chebli zu Hate Speech: "Es gibt eine autoritäre Revolte" [Sawsan Chebli on hate speech: "There is an authoritarian revolt"]. Vorwärts. https://www.vorwaerts.de/ artikel/sawsan-chebli-hate-speech-gibt-autoritaererevolte-0

Kolko, B. E., Nakamura, L., \& Rodman, G. B. (2000). Race in cyberspace. Routledge.

Michailidou, A., Trenz, H.-J., \& De Wilde, P. (2014). The internet and European integration: Pro- and anti-EU debates in online news media. Barbara Budrich Publishers.

MP Anna Soubry contacts police over "Jo Cox" tweet. (2016, December 2). BBC News. https://www.bbc.co. uk/news/uk-england-nottinghamshire-38180748

Parliament TV. (2017, July 12). Diane Abbott's powerful speech describing "mindless" online abuse-video. The Guardian. https://www.theguardian.com/ politics/video/2017/jul/12/diane-abbotts-powerfulspeech-describing-mindless-online-abuse-video

Pavan, E., \& Caiani, M. (2017). "Not in my Europe": Extreme right online networks and their contestation of EU legitimacy. In M. Caiani \& S. Guerra (Eds.), Euroscepticism, democracy and the media: Communicating Europe, contesting Europe (pp. 169-193). Palgrave Macmillan.

Pearce, R., Erikainen, S., \& Vincent, B. (2020). Afterword: TERF wars in the time of Covid-19. The Sociological Review, 68(4), 882-888.

Perraudin, F., \& Murphy, S. (2019, October 31). Alarm over number of female MPs stepping down after abuse. The Guardian. https://www.theguardian. com/politics/2019/oct/31/alarm-over-numberfemale-mps-stepping-down-after-abuse

Phipps, A. (2021). White tears, white rage: Victimhood and (as) violence in mainstream feminism. European Journal of Cultural Studies, 24(1), 81-93.

Roose, J., Sommer, M., Scholl, F., Kousis, M., Kanellopoulos, K., \& Loukakis, A. (2017). Debating responsibility on the eurozone crisis in traditional media newspaper reporting in Greece and Germany under a social media lens. In M. Barisone \& A. Michailidou (Eds.),
Social media and European politics (pp. 267-290). Palgrave.

Scott, J. (2020, September 23). Misogyny: Women "should be protected" under hate crime laws. $B B C$ News. https://www.bbc.co.uk/news/uk-politics54254541

Siim, B. (2012). Intersections of gender and diversityA European perspective. In B. Siim \& M. Mokre (Eds.), Negotiating gender and diversity in an emergent European public sphere (pp. 3-21). Palgrave Macmillan.

Siim, B. (2014). Political intersectionality and democratic politics in the European public sphere. Politics \& Gender, 10(1), 117-124.

Smith, N. J. (2020). Capitalism's sexual history. Oxford University Press.

Smith, N. J., \& Lee, D. (2015). What's queer about political science? The British Journal of Politics and International Relations, 17(1), 49-63.

Snowdon, K. (2018, June 12). Labour MP Jess Phillips received more than 600 rape threats in one night. HuffPost. https://www.huffingtonpost.co.uk/entry/ labour-mp-jess-phillips-600-rape-threats_uk_ 5b1f894be4b0bbb7a0e1147b

Sobande, F. (2020). The digital lives of Black women in Britain. Springer.

Southern, R., \& Harmer, E. (2019). Twitter, Incivility and "everyday" gendered othering: An analysis of Tweets sent to UK Members of Parliament. Social Science Computer Review, 39(2), 259-275.

Straatmann, L. (2021, April 8). Monitor: Hass und Hetze im Netz: Kaum Schutz für Opfer [“Monitor: Online hate and harassment: There's hardly any protection for victims"]. Das Erste. https://www1.wdr.de/ daserste/monitor/sendungen/hetzte-im-netz100.amp

Syal, R. (2019, May 7). Police investigate UKIP candidate over Jess Phillips rape comments. The Guardian. https://www.theguardian.com/politics/2019/may/ 07/police-investigating-ukip-candidate-youtubecarl-benjamin-jess-phillips-comments

Urwin, R. (2020, November 1). Luciana Berger interview: I'm still hounded for being Jewish-and I know Jeremy Corbyn is antisemitic. The Sunday Times. https://www.thetimes.co.uk/article/luciana-bergerinterview-im-still-hounded-for-being-jewish-and-iknow-jeremy-corbyn-is-antisemitic-9n35dn5f5

Wahba, D. (2016). Gendering the Egyptian revolution. In F. Sadiqi (Ed.), Women's movements in Post"Arab Spring" North Africa (pp. 61-74). Palgrave Macmillan.

Walker, P. (2017, December 15). Anna Soubry receives messages calling for her to be hanged as a traitor. The Guardian. https://www.theguardian.com/politics/ 2017/dec/15/anna-soubry-receives-messagescalling-for-her-to-be-hanged-as-a-traitor-brexit

Zimmerman, T. (2017). Intersectionality: The fourth wave feminist Twitter community. Atlantis, 38(1), 54-70. 
About the Author

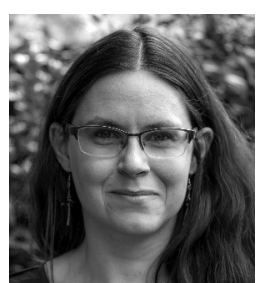

Charlotte Galpin is associate professor in German and European politics in the Department of Political Science and International Studies at the University of Birmingham. Her research focuses on European identities, EU citizenship, Euroscepticism, and the European Public Sphere. She has published in journals including Citizenship Studies, Comparative European Politics, Journal of Common Market Studies, Journalism Practice, and the British Journal of Politics and International Relations. Her monograph, The Euro Crisis and European Identities, was published in 2017 with Palgrave Macmillan. 